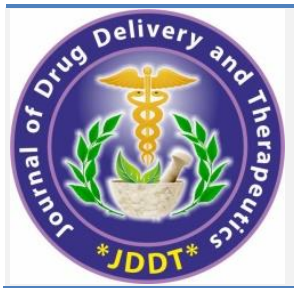

Access Full Text Article
Available online on 15.06.2021 at http://jddtonline.info

\section{Journal of Drug Delivery and Therapeutics}

Open Access to Pharmaceutical and Medical Research

Copyright (C) 2021 The Author(s): This is an open-access article distributed under the terms of the CC BY-NC 4.0 which permits unrestricted use, distribution, and reproduction in any medium for non-commercial use provided the original author and source are credited

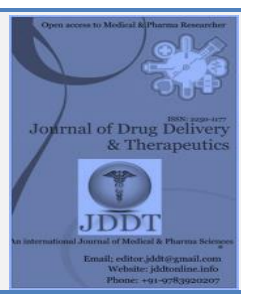

Review Article

\title{
A Retrospective Assessment of the Initial Phase of Covid-19 and its Implemented Treatment Strategies
}

\author{
(D) Pinkan Sadhukhan ${ }^{1}$, DInnocent Sutnga*1, (DBharjil Bingari1, (D)Ananta Choudhury ${ }^{2}$ \\ ${ }^{1}$ Department of Pharmaceutical Sciences, Dibrugarh University, Dibrugarh, Assam, 786004, India \\ ${ }^{2}$ Faculty of Pharmaceutical Science, Assam down town University, Panikhaiti, Guwahati, Assam, 781026, India
}

\begin{tabular}{ll}
\hline Article Info: & \\
& $\begin{array}{l}\text { Article History: } \\
\text { Review Completed 18 May } 2021 \\
\text { Accepted 23 May 2021 } \\
\text { Available online 15 June } 2021\end{array}$
\end{tabular}

Cite this article as:

Sadhukhan P, Sutnga I, Bingari B, Choudhury A, A Retrospective Assessment of the Initial Phase of Covid-19 and its Implemented Treatment Strategies, Journal of Drug Delivery and Therapeutics. 2021; 11(3-S):81-89

DOI: http://dx.doi.org/10.22270/jddt.v11i3-S.4868

\section{*Address for Correspondence:}

Innocent Sutnga, Department of Pharmaceutical Sciences, Dibrugarh University, Dibrugarh, Assam, 786004, India. Email: innocv11@gmail.com ORCID ID: https://orcid.org/0000-0001-7331-6821

\section{Abstract}

Coronaviridae is a typical type of viral family comprised of an exceptionally huge RNA genome with a characteristic appearance and a noteworthy propensity to move from creatures to people. Since the start of the 21st century, three exceptionally contagious and pathogenic coronaviruses have traversed the species boundary and caused lethal pneumonia, exacting serious episodes, and causing human wellbeing crises to an unfathomable extent. The COVID-19 pandemic, presumably, is the most wrecking one, over the most recent 100 years after Spanish influenza. To the quick assessment of the various methodologies for a capability to evoke defensive resistance and well-being to shorten undesirable resistant potentiation, which assumes a significant function in this virus's pathogenesis. Considering the forthcoming public health crisis, researchers around the globe are consolidating their logical scientific possessions and offering initial information in an unprecedented way. In this review, we have tried to summarize some of the SARnCoV2 treatments that essentially focus on the potential drugs including Lopinavir/Ritonavir, Favipiravir, Remdesivir, Chloroquine phosphate, Hydroxychloroquine, Arbidol, and so on. Other potential vaccine developments with their difficulties associated and their current status are also being addressed.

Keywords: Coronaviridae, COVID-19 pandemic, Corona Virus, Potential antiviral drugs SARS-CoV-2, Vaccine against SARS-CoV-2.

\section{Introduction}

Severe acute respiratory syndrome (SARS) was first expressed as a disorder of unidentified etiology in China, in 2002. As referred to by the World Health Organization (WHO), the pandemic has spread to 29 nations. The report says that in tally, around 8096 people were exposed to SARS infection and out of which 774 deaths were recorded 1 . Recently, the worldwide outbreak of novel COVID-19, which is reported to be caused by SARS-CoV-2. SARS-CoV-2 is a novel beta coronavirus with sequenced genes ranging from $29 \cdot 8 \mathrm{k}$ to $29 \cdot 9 \mathrm{k}$ RNA bases ${ }^{2-3}$. The SARS-CoV-2 genome codes entail structural proteins, replicate proteins, and accessory proteins. The ORF1ab \& ORF1a polyproteins are proteolytically divided into 16 nonstructural proteins designated as nsp1-16 ${ }^{4}$. Like SARS, the most destructive and fatal effects of SARS-CoV-2 have already created a huge impact worldwide 5. SARS-CoV-2 affects the lower respiratory system and causes viral pneumonia; however, it might likewise influence the heart, gastrointestinal system, kidney, central nervous system, and kidney following multiple organ failure 6 . The purpose of this review is to clarify the advancement made in the improvement of SARS species and to determine the gaps in the scientific understanding that needs to be completed. By talking about and overcoming these challenges and implementing improvements made, an effective and safe vaccine can be achieved.

\section{Molecular biology of the COVID-19}

SARS-CoV-2 falls under the family Coronaviridae, classified as a subfamily of the ortho-coronaviridae, the seventh member of this family that infects people. Its members have named afterward their crown-like appearance under an electron microscope caused by excess glycoproteins that help identify and bind to the cell receptor ${ }^{7}$. A few conspicuous features of this novel coronavirus suggest that they are from bat-origin. The genome sequences \& phylogenetic analysis show that this novel coronavirus is nearly like that of bat-originated coronavirus (SL-CoV ZC45) 8. All these novel coronaviruses contain intact ORF8 \& ORF3 gene regions. These are typical features of bat-origin coronaviruses ${ }^{9}$. Another piece of proof supporting COVID-19 has bat origins in the presence of high levels of ACE2 receptor homology from an assortment of creature species, hence affecting these species such as intermediate chemicals or animal species of COVID-19 diseases ${ }^{10}$. In terms of genetic sequence ownership and phylogenetic reports, SARS-CoV-2 is altogether unique concerning coronavirus and can consequently be viewed as another beta coronavirus that taints people 11. However, amino acid sequences for the seven stored ORF1ab domains used for the classification of Coronaviruses strains were $94.4 \%$ like the $2019-\mathrm{nCoV}$ and SARS-CoV strains, suggesting that the two viruses are the same type, SARS-CoV ${ }^{12}$. Its genomes are usually composed of a 50-methylguanosine cap initially, a 30-poly-A tail at the 
end, and a total of 6-10 genes in between the structural proteins, including spike (S), envelope (E), and the membrane (M) that makes up the viral coat, as well as the nucleocapsid $(\mathrm{N})$ protein that binds to the viral genome, is translated from subgenomic RNA 13. A portion of these proteins gets glycosylated from Golgi substances to form glycoproteins. The $S$ protein is made up of glycosylated and is required for bacterial binding and is potentially infectious and binds the virus to infected cells. The $S$ protein is recommended by host cell protease and is detected by the cellular receptors ACE2 and TMPRSS2. is said to be locked by the clinically proven protease inhibitor ${ }^{14-15}$.

\section{Immunological features associated with COVID-19}

Mainly, flu-like symptoms and typical pneumonia, are the characteristic of SARS-CoV infection, usually like a normal cold and influenza and do not become severe, including cough, sore throat, and breathing problems 16 . Most patients also developed lymphopenia and pneumonia with characteristic pulmonary ground-glass opacity changes on chest CT. It attacks other significant organs in the body, like the kidneys, which may cause organ failure ${ }^{17}$. Recent studies have found that the virus may affect renal tubular cells and testicular cells due to the high expression of ACE2. It also found that COVID-19 destroys gastrointestinal bacteria which lead to problems with the digestive system, for example, loss of appetite, vomiting, and diarrhea ${ }^{18}$. Besides, a study in China with more than a thousand hospitalized patients shows more elevated levels of proinflammatory cytokines including IL-2, IL-10, IL-7, G-CSF, IP-10, MIP-1A,
MCP-1, and TNF $\alpha$ were seen in the COVID-19 severe cases 19. These findings are consistent with MERS and SARS in that the presence of lymphopenia and "cytokine storm" may assume a noteworthy function in the pathogenesis of COVID19. This so-called "cytokine storm" can trigger viral sepsis and lung damage caused by other problems including pneumonitis, respiratory failure, acute respiratory syndrome (ARDS), shock, body failure death 20. Major viral host interaction may include delayed Type I IFN response during initial infection, hyperinflammatory conditions triggered by viral replication, influx of activated neutrophils and inflammatory monocytes/macrophages, production of specific antibodies \& induction of Th1/Th17. In an initial study, one patient from a group showed peak specific IgM on day 9 after disease onset and then switched to IgG by week 2 . Interestingly, antibodies from 5 patients of confirmed COVID-19 show some cross-reactivity with SARS-CoV, but not other coronaviruses. Besides, all antibodies from patients were able to deplete SARS-CoV-2 in an in vitro plaque assay, suggesting that there may be an increase in humoral responses 21 .

\section{Potential drugs for the COVID-19 treatment}

Various potential drugs indicate promising antiviral activity against SAR-CoV2. The list of clinical trials utilizing drug compounds to treat COVID-19 patients in Table I. Currently, numerous drugs and medications are being utilized in health facilities worldwide to test their viability, including lopinavir/ritonavir, chloroquine, hydroxychloroquine, arbidol, remdesivir, favipiravir, and so on 22 .

Table I: Some potential antiviral drugs for COVID-19 patients undergoing clinical trials identified at https://clinicaltrials.gov/55

\begin{tabular}{|c|c|c|c|}
\hline Compound & Phase & $\begin{array}{l}\text { Clinical Trial } \\
\text { number }\end{array}$ & Sponsors \\
\hline Lopinavir/Ritonavir & Phase 3 & NCT04321174 & Darrell Tan \\
\hline $\begin{array}{l}\text { Lopinavir/Ritonavir, Ribavirin and } \\
\text { IFN-beta Combination }\end{array}$ & Phase 2 & NCT04276688 & University of Hong Kong, Hospital Authority \\
\hline Chloroquine Phosphate (CQ) & Phase 2 & NCT04328493 & Oxford University Clinical Research Unit, Vietnam \\
\hline Chloroquine Phosphate (CQ) & Phase 2 & NCT04333628 & HaEmek Medical Center, Israel \\
\hline Hydroxychloroquine (HCQ) & Phase 3 & NCT04330144 & Gangnam Severance Hospital \\
\hline $\begin{array}{l}\text { Azithromycin- Hydroxychloroquine } \\
\text { Combination or Hydroxychloroquine }\end{array}$ & Phase 2 & NCT04336332 & Rutgers, The State University of New Jersey \\
\hline Remdesivir (GS-5734) & Expanded & NCT04323761 & Gilead Sciences \\
\hline Remdesivir (GS-5734) & Phase 3 & NCT04292899 & Gilead Sciences \\
\hline Favipiravir (T-705) & Phase 3 & NCT04336904 & Giuliano Rizzardini \\
\hline Favipiravir (T-705) & Phase 2 & NCT04346628 & Stanford University \\
\hline Baricitinib & Phase $2 / 3$ & NCT04320277 & Hospital of Prato \\
\hline Baricitinib & Phase $2 / 3$ & NCT04340232 & University of Colorado, Denver \\
\hline Galidesivir (BCX4430) & Phase 1 & NCT03891420 & BioCryst Pharmaceuticals \\
\hline Darunavir and Cobicistat & Phase 3 & NCT04252274 & Shanghai Public Health Clinical Center \\
\hline $\begin{array}{l}\text { Hydroxychloroquine, Oseltamivir, or } \\
\text { Azithromycin }\end{array}$ & Phase 3 & NCT04338698 & Shehnoor Azhar \\
\hline CamostatMesylate & Phase 1 & NCT04321096 & University of Aarhus \\
\hline Arbidol (Umifenovir) & Phase 4 & NCT04350684 & Shahid Beheshti University of Medical Sciences \\
\hline Arbidol (Umifenovir) & Phase 4 & NCT04260594 & Jieming QU \\
\hline
\end{tabular}




\section{Lopinavir/ritonavir (LPV/r)}

Lopinavir/ritonavir (LPV/r), a protease inhibitor produced by AbbVie Corporation, is utilized for treating HIV-1 disease. The synthetic structure of Lopinavir is $(2 \mathrm{~S})$ eN-[(2S,4S,5S)-5[[2-(2,6-dimethylphenoxy) acetyl] amino]-4-hydroxy-1,6diphenyl-hexan-2-yl]-3-methyl-2-(2-xo-1,3-diazinon-1-yl) butanamide. It is the dynamic segment of this medication combination, which blocks the division of Gag-Pol polyproteins, bringing about the creation of youthful virus particles unequipped for infecting the patients further. In any case, LPV has no impact on cells having incorporated viral DNA. What's more, it just forestalls ensuing contamination of other vulnerable cells 22. Pharmacokinetic studies have indicated that lopinavir is essentially utilized by CYP3A4 and delivers low fundamental focuses at the point when utilized alone. Nonetheless, the metabolism of lopinavir could be repressed by ritonavir. Consequently, a mix of these two medications could draw out the fundamental introduction to lopinavir and keep the lopinavir fixation in the flow for a more extended time ${ }^{23}$. Diarrhea and other gastrointestinal problems, asthenia, headache, and skin rashes are the most common side effects in adults taking LPV/r medication 22. Recently, a clinical trial (NCT04321174) is selecting members to additionally assess the adequacy of LPV/r for treating COVID-19 patients in Table I.

\section{Chloroquine phosphate}

Chloroquine phosphate is a water-dissolvable compound with the structure of 7-chloro-4-((40-diethylamino-1-methyl butyl) amino) quinoline diphosphate, which is broadly utilized for treating malaria disease and immune system infections, like lupus (both discoid lupus erythematosus and fundamental lupus erythematosus) and joint pain. It is the main principal line infection changing hostile to rheumatic medications utilized for treating rheumatoid arthritis (RA) and it acts by hindering antigen introduction limit of dendritic cells, cytokine creation in macrophages, just as calcium and toll-like receptor (TLR) motioning in $\mathrm{B}, \mathrm{T}$, and other immune cells. Chloroquine is chiefly ingested from the gastrointestinal lot, and it may hinder the virus infection by expanding the endosomal $\mathrm{pH}$ required for virus/cell combination, just as by meddling with the glycosylation of cell receptors of SARS-CoV 24. While patients reported few side effects in clinics when given the standard dose of chloroquine, the most serious side effects include retinopathy, cardiomyopathy, and neuromyopathy when given for longer periods, and acute toxicity of chloroquine occurred when a high dose was given quickly through parenteral routes 22. Recently, numerous clinical preliminaries with chloroquine against 2019-nCoV were started in numerous medical care hospitals in Table I.

\section{Hydroxychloroquine (HCQ)}

Hydroxychloroquine (HCQ) is an aminoquinoline compound adjusted by chloroquine, with an N-hydroxyethyl side chain rather than the N-diethyl gathering of chloroquine. An expansion in hydroxyl moiety makes it profoundly water solvent and less harmful than chloroquine, while yet holding the antiviral action. The immunomodulatory systems are like chloroquine by hoisting the $\mathrm{pH}$ through amassing in lysosomes. In this way, HCQ interferes in the cycle of antigen introduction and perhaps constricting the inflammatory reaction by essentially diminishing the creation of proinflammatory factors in COVID-19 patients. A blend of HCQ and azithromycin likewise indicated synergistic impact, giving a substitute treatment system for SARS-CoV-2 infection. Although HCQ is a less harmful particle, harm happens with its drawn-out use and over-measurement, especially irreversible retinopathy, perhaps prompting the loss of vision 25. Hence, clinical checking and early acknowledgment of poisonous manifestations are fundamental for a viable administration procedure. Clinicians should screen the portion taken by the patients and pay close consideration regarding the side effects including neuromyopathy, retinal toxicity, and heart infection during clinical trials. Be that as it may, at present, there is still no reasonable proof to help the adequacy of HCQ against SARS-CoV-2 infection, ${ }^{26}$ which stays to be affirmed by clinical trials in Table I.

\section{Arbidol (ARB)}

Arbidol (ARB), otherwise called umifenovir, is suggested as an explicit anti-influenza drug to control influenza $A$ and influenza B. The drug has been endorsed in Russia and China for clinical use, with no major adverse effects reported to date. It forestalls contact between the virus and host cells and infiltration of virus particles into the cell by restraining the combination of the infection lipid shell to the cell membrane ${ }^{27}$. Hence, a review study affirmed by the Third People's Hospital of Changzhou, China exhibited the adequacy of ARB monotherapy, which may be better than $\mathrm{LPV} / \mathrm{r}$ against COVID-19. In any case, the current information with clinical trials is deficient to unequivocally demonstrate the viability of ARB against COVID-19 as a result of the restricted example size, and the obscure antiviral mechanisms. Another examination affirmed that ARB combined with LPV/r may profit the patients by postponing the movement of lung sores and bringing down the chance of respiratory and gastrointestinal transmissions. Consequently, blend treatment could be the best method for the management of COVID-19, which should be approved sooner rather than later ${ }^{28}$. Several adverse effects were reported, the most common of which were gastrointestinal side effects and elevated transaminase levels ${ }^{22}$. At present, stage IV clinical trials are being completed to test the adequacy of ARB against COVID-19 counting NCT04350684 and NCT04260594 in Table I.

\section{Remdesivir}

Remdesivir (GS-5734), a prodrug created by Gilead Science, is all around perceived as an expected antiviral medication against a wide exhibit of diseases with RNA viruses in cell cultures, mice, and non-human primate (NHP) models. The anticipated mechanism of activity is by the joining of a functioning triphosphate into the viral RNA bringing about the untimely end of RNA synthesis that diminished the degree of viral RNA ${ }^{29}$. In $12 \%$ of the participants, serious side effects including hypotension, acute kidney injury, septic shock, and multiple organ dysfunction syndromes were recorded 22. In any case, a report distributed in the New England Journal of Medicine depicted the impact of GS-5734 was yet lacking to evaluate in the first COVID-19 patient recovered after Remdesivir infusion in the United States because the viral heap of the patient was diminished before Remdesivir was utilized. Subsequently, the patient recovery was inferable from the medication or the job of self-defense mechanisms, and steady medicines were most certainly not clarified ${ }^{30}$. As of now, clinical trials utilizing GS-5734 as a remedial against 2019-nCoV infection are in progress (NCT04323761 and NCT04292899), and the adequacy and unfriendly responses of this medication are deserving of our consideration in Table I.

\section{Favipiravir (FPV)}

Favipiravir (T-705), 6-Fluoro-3-hydroxypyrazine-2carboxamide, is a novel RNA-dependent RNA polymerase (RdRp) Inhibitor from Toyama Chemical Co., Ltd, and is used to treat common flu infections in Japan. Favipiravir-RTP 
(favipiravir ribofuranosyl-50-triphosphate) is the dynamic type of T-705 changed over by chemicals, which goes about as a nucleotide analog selectively hindering the RdRp. Simultaneously, T-705 can likewise get joined into the incipient viral RNA resulting at the end of the viral replication measures. Another examination looked at the impacts of FPV and LPV/r for treating Coronavirus patients. FPV would do well to treatment consequences for COVID-19 contrasted with LPV/r having a quicker viral clearance rate and a higher level of progress from lung entanglements as proven by imaging methods 31 . In any case, the creation and use of T-705 are seriously limited in Japan as a result of the common dangers of teratogenicity and embryotoxicity 32 . Currently, a stage III clinical preliminary of T-705 (NCT04336904) is now in progress as in Table I.

\section{Others' antiviral drugs}

Ribavirin is known as a viable antiviral drug to battle the hepatitis C virus (HCV) yet it is profoundly cytotoxic 33 . Indeed, at that point, it was remembered for the suggested combination treatment with interferon or $\mathrm{LPV} / \mathrm{r}$ in the diagnosis and treatment guidelines of the $2019-\mathrm{nCoV}$ in China (the seventh version). Be that as it may, there was lack of proof accessible for its clinical adequacy after administration to COVID-19 patients. A Janus kinase inhibitor, baricitinib, which ties to the cyclin G-related kinase, is a controller of endocytosis. Analysts utilized AI to look for the affirmed medicates that could help in the treatment of COVID-19 disease and found baricitinib as a potential drug to treat $2019-\mathrm{nCoV}$ acute respiratory illness 34. As of late, the clinical trials of baricitinib against COVID-19 (NCT04320277 and NCT04340232) are progressing and the outcomes are energetically anticipated 35 . Lanjuan Li group has indicated Darunavir, an HIV-1 protease inhibitor, has action against 2019-nCoV. Darunavir might be directed alongside either cobicistat or ritonavir. However, the adequacy and safety profile are yet to be investigated 36 . As of now, the stage III clinical trials of Darunavir along with Cobicistat against Coronavirus are in progress. Oseltamivir is a medication utilized for forestalling and treating influenza virus infection in children. It was gone after for the treatment of SARS-CoV-2 patients; 37 However, its adequacy stays dubious.

\section{Considerations in vaccine development}

Demographic changes might affect the epidemiology of COVID-19 and so the retardation of the vaccine development process ${ }^{38}$. Previous clinical trials on vaccine candidates of the severe acute respiratory syndrome (SARS) have shown a deadly immune system interaction and those then exposed to the virus developed more complicated disease than those who were unvaccinated. This immune backfiring additionally called an insusceptible upgrade, may build up antibodydependent enhancement (ADE), a cycle where a virus exploits antibodies to advance disease or a class of Th2 immunopathology that initiates hypersensitive inflammation in the patient $39,45-46$. Cats immunized against fractional inactivated poliovirus vaccine (fiPV) got more diseased than cats who were not vaccinated 40 . It is to be found that reinfections by COVID-19 are possible because no hard immunity develops in the body even after getting cured of the infection 41 . Protective immunity develops after the second vaccination, which can be given after 3-4 weeks of the first shot and may last up to only one to two weeks. So, the vaccine to be developed should target to achieve a long-time immunity against the virus ${ }^{42}$. Due to the mutation and demographic variation of the virus, a detailed understanding of the genome \& pathogenic mechanism of SARS-CoV is still not possible ${ }^{48-49}$. Different pathogenesis in animal models of
SARS-CoV infection couldn't reenact human disease 51 . Researchers found that normally lab-animals don't have the receptor-binding domains like humans. However, Bao et al. tested the pathogenicity of SARS-CoV-2 in ACE2 receptorexpressing transgenic mice show mild disease. So, here again, the vaccine development process will face a barrier to clinical trials 43. Previous research claims that immune senescence occurs in older people aged 65 or above, which lowers the vaccine responses on them ${ }^{44}$. Clinical trial NCT04348370 is running to test the efficacy of the bacille Calmette-Guerin (BCG) vaccine on the COVID-19 pandemic but the WHO clearly stated that it does not recommend such vaccination against COVID-19 54.

\section{Animal models}

A remarkable advance in SARS research came with the discovery that ACE2 receptor overexpressed transgenic mice were prone to infection with SARS-CoV 2, Interstitial pneumonia \& Specific IgG antibodies against S protein SARSCoV-2 was positively measured in those mice 46 . From previous research, it is documented that domestic ferrets \& cats can be a promising animal model for SARS-CoV. Ferrets show alveolar damage, elevated liver enzymes, and lymphocytic infiltration, which is quite like humans. A recent study also claimed ferrets \& cats are highly permissive towards SARS-CoV2 infection ${ }^{39}$. These models are a promising contender for preclinical research yet don't completely mimic the clinical disease. SARS-CoV-2 causes disease in cynomolgus macaques like COVID19 which can be a novel infection model that can help in evaluating the efficacy of repurposing species-specific existing treatment. Patent application W02017095875 mentioned the arrangement of human antibodies and immune conjugates explicitly focusing on chemokine IP-10, including an anti-IP10 antibody, which appeared to stifle free serum IP-10 in around 3 days in Cynomolgus macaques ${ }^{40}$. The golden hamster or Syrian hamster also supports the SARS-CoV-2 infection and shows an immune response the same as humans when infected. It is also capable of transmission, so it could be a prompt model for vaccine development. However, a successful animal model trial cannot be considered as a clinically effective vaccine because of some higher physiological barriers in humans ${ }^{47}$. So, the usage of such models should be reduced to an extent. But the alternative models which may run on computers are not properly developed yet or need some more research. So, now our uttermost responsibility is to save human lives, which may cost some sacrifice 48 .

\section{Various vaccines mechanism of action}

The best-authorized vaccines evoke long-haul antigenexplicit antibody responses by plasma cells notwithstanding the turn of events of persisting $\mathrm{T}$ cell and B cell memory. If there should be an occurrence of SARS-CoV infection, both humoral and cellular immune responses are critical for the freedom of infection ${ }^{38}$. Recombinant virus vectors work in a comparable way like an endogenous microbe, by communicating axenic target protein in the cytoplasm of the host cell. In the wake of handling of such endogenous antigen, MHC class 1 molecule presents them to CD8+ T lymphocytes, which causes the creation of T-cytotoxic cells. This pathway prompts the foundation of cell-interceded insusceptibility, which is urgent in disposing of viruscontaminated cells. Subunit vaccine applicants, especially RBD of $S$ protein of SARS-CoV contain major antigenic determinants that can actuate killing antibodies. The SARSCoV S protein can likewise actuate CD8+ T-cell reactions 39. The RBD of $\mathrm{S}$ protein contains various adaptation subordinate epitopes and is the primary area that actuates 
killing antibody and T-cell resistant reactions against SARS$\mathrm{CoV}$ contamination, making it a significant focus for antibody improvement. The methodologies for creating RBD-based antibodies against SARS-CoV have given valuable data to planning safe and powerful immunizations against SARS-CoV 2 since RBDs of SARS-CoV 2 additionally contain comparative epitopes. Also, Adenoviral vectors can initiate intense antibody just as $\mathrm{T}$ cell reactions with varieties in the resistant reaction relying upon the serotype utilized. Replication-lacking Ad5, one of the most generally utilized adenoviral vectors, can initiate astoundingly intense CD8+ T cells just as antibody reactions ${ }^{49}$. Besides, DNA immunization is additionally ready to inspire both humoral and cell safe reactions, through actuation of CD8+ cytotoxic and CD4+ aide T cells, individually, upon a passage in the cell, DNA vaccines are detected by an assortment of innate insusceptible receptors, for example, STING/TBK1/IRF3 pathways and the AIM2 inflammasome and numerous different variables are associated with DNA immunization method of activity however the specific mechanism of action is yet to be assessed 50 . Nonetheless, inoculation with $\mathrm{S}$ protein-encoding DNA vaccine defensive invulnerability against SARS-CoV infection in a mouse model by instigating $\mathrm{T}$ cell and killing antibody reactions 51 .

\section{RNA viruses and challenges for vaccine development}

RNA viruses recreate through RNA-subordinate, RNA polymerase encoded by the infection. This sort of polymerase has no editing instrument related to it, which brings about a high pace of uncorrected mutations ${ }^{1}$. These changes might be deadly to virus replication and may even continue, bringing about the fast development of the virus. Thus, numerous RNA infections have different genomic strains, or quasi-species, present at once in a person. Silent mutation in the RdRp gene has been noticed in North America \& Italy, also in India where the maximum number of mutations were identified in Indian sequence-located in ORF1ab, nsp2, nsp3, helicase, ORF8 protein, and spike surface glycoprotein, and a unique mutation identified in the spike surface glycoprotein in the Indian sequence ${ }^{48}$. Most coronaviruses are thought to be able to replicate due to the homologous sequence at the end of 5 and $3 \mathrm{mRNAs}$. Evidence suggests that SARS-CoV was initiated by reunification between coronaviruses and that there was an increase in genetic diversity ${ }^{52}$.

\section{Potential vaccine candidates and prototypes}

As per the DRAFT scene of COVID-19 candidate vaccines by WHO, major types include non-replicating viral vectors, DNA-based vaccines, mRNA-based vaccines, and inactivated virus and recombinant protein-based vaccine 53 . Table II shows a list of accepted patents regarding SARS vaccine development.

\section{Attenuated Virus Vaccines}

This is an existing licensed human vaccine platform. It is a straightforward cycle utilized for a few authorized human vaccines; the existing framework can be utilized for largescale manufacturing. Patent application US20060039926 reveals live attenuated coronavirus or torovirus immunizations. By the fifth day after intracerebral injection, the mice exhibited a low replication of the attenuated MHV virus. When all is said in done, the creation of irresistible clones for COVID vaccine seeds requires significant investment because of the huge genetic size (30.0 KB). Safety checks should be extensive 4. For example, Indian Immunologicals Ltd/Griffith University, Codagenix/Serum
Institute of India, Mehmet Ali Aydinlar University/Acibadem Labmed Health Services are separately working on Live Attenuated vaccine targeting SARS-COV2, but all three are in the clinical trial phase 39 .

\section{DNA-Based Vaccines}

This is a non-licensed vaccine platform. It mainly targets the Spike protein (S). Currently, DNA-Based vaccine candidates running in clinical trial Phase-1 for COVID-19 involves Patent application NCT04336410 which shows DNA plasmid encoding $\mathrm{S}$ protein. It is delivered by electroporation method named INO-4800 innovated by Inovio Pharmaceuticals planned for a human trial. Patent application W02005081716 uncovers structures and techniques for instigating and improving resistant reactions, especially antigen-explicit CD8+ $\mathrm{T}$ cell-mediated reactions, against antigens of the SARS COVID-19. For example, as 12th April 2021 report by WHO on "DRAFT scene of COVID-19 candidate vaccines.pdf", only 4 out of 16 DNA Vaccine candidates got consent to direct a Phase 2 trial 36,39.

\section{Recombinant proteins and virus-like particles}

This is a partially licensed vaccine platform limited to baculovirus (influenza, HPV). It mainly targets the Spike protein (S). No irresistible virus should be taken care of adjuvants can be utilized to expand immunogenicity. Patent application W02010063685 by GlaxoSmithKline (GSK) reveals an immunization that can exasperate a defensive invulnerable reaction against SARS. The vaccine contains an oil-in-water emulsion adjuvant and S protein immunogen 4 . Patent US2007000357 describes Purified trimeric S protein as a vaccine against severe acute respiratory syndrome virus infections. For example, Generex announced a developing COVID-19 vaccine in patent US20060002947 describes Iikey/antigenic epitope hybrid peptide vaccines. The organization will use its Ii-Key insusceptible framework initiation innovation to deliver a COVID-19 viral peptide for human clinical trials 53 .

\section{Viral vector-based vaccines}

This is a partially licensed vaccine platform limited to VSV (Ervebo) but not for the viral vectored vaccines. It also targets Spike $(S)$ proteins. No such irresistible virus should be taken care of, it as of now has some phenomenal preclinical and clinical information for some rising viruses, including MERS-CoV. Later, Vector insusceptibility may contrarily influence antibody viability (contingent upon the vector picked) ${ }^{4}$. For example, Viral-vector-based vaccines (focused on the S protein, e.g., Vaxart, Geovax, University of Oxford, and Cansino Biologics) J \& J is using an experimental adenovirus vector platform that has not yet resulted in a licensed vaccine. As the 12th April 2021 report by WHO on "DRAFT scene of COVID-19 candidate vaccines.pdf", only 4 out of 43 viral vector Vaccine candidates can conduct phase 3 trial. Those four candidates are based on a non-replicating viral vector 43 .

\section{mRNA-Based Vaccines}

Here, no such irresistible virus needs to be treated, vaccines are usually immunogenic, rapid production is possible. Safety issues with reactogenicity have been reported. The mRNA-based vaccine, which produces a target in vivo vaccine after injecting mRNA into lipid nanoparticles, has been produced in collaboration with Moderna and the vaccine research center at the National Institutes of Health. A clinical trial has just begun (ClinicalTrials.gov: NCT04283461). Curevac works with a nearly similar vaccine but it is in the clinical trial phase. Patent W02017070626 application by Moderna produces mRNA drugs made from 
mRNAs encoding antigenic viral full-length $S$, S1, or S2 protein from SARS-CoV and MERS-CoV infection, figured in cationic lipid nanoparticles. They reveal that mice inoculated with mRNA encoding Coronavirus full-length $S$ protein delivered higher antibody titers contrasted with mRNA encoding the S protein S2 subunit ${ }^{50}$. As in 12th April 2021 report by WHO on "DRAFT scene of COVID-19 candidate vaccines.pdf", only 2 of the 23 mRNAs vaccines used to receive (one from Moderna and the other from BioNTech Pharmaceuticals) approval for a phase 3 trial and both are lipid nanoparticle-based delivery 55 .

Table II: List of some SARS-CoV-2 vaccine undergoing clinical trials currently and candidates for the development of a safe and effective Vaccine 55 .

\begin{tabular}{|c|c|c|c|c|}
\hline Vaccine & Phase & $\begin{array}{l}\text { Clinical Trial } \\
\text { number }\end{array}$ & Institute & Sponsor \\
\hline mRNA-1273 & Phase-1 & NCT04283461 & $\begin{array}{l}\text { Emory Vaccine Center-The Hope } \\
\text { Clinic, Decatur, Georgia, United State }\end{array}$ & $\begin{array}{l}\text { National Institute of Allergy } \\
\text { and Infectious Disease } \\
\text { (NIAID) }\end{array}$ \\
\hline Gam-COVID-Vac & $\begin{array}{l}\text { Phase- } \\
1 / 2\end{array}$ & NCT04436471 & $\begin{array}{l}\text { Main military clinical hospital named } \\
\text { after academician N. N. Burdenko } \\
\text { Moscow, Russian Federation }\end{array}$ & $\begin{array}{l}\text { Gamaleya Research Institute } \\
\text { of Epidemiology and } \\
\text { Microbiology, Russia }\end{array}$ \\
\hline $\begin{array}{l}\text { Pathogen-specific } \\
\text { APC }\end{array}$ & Phase-1 & NCT04299724 & $\begin{array}{l}\text { Shenzhen Genoimmune Medical } \\
\text { Institute Shenzhen, Guangdong, China }\end{array}$ & $\begin{array}{l}\text { Shenzhen Geno-Immune } \\
\text { Medical Institute }\end{array}$ \\
\hline $\begin{array}{l}\text { Antigen-specific } \\
\text { CTLs, injection and } \\
\text { infusion of } \\
\text { LVSMENP- DC } \\
\text { vaccine }\end{array}$ & $\begin{array}{l}\text { Phase- } \\
1 / 2\end{array}$ & NCT04276896 & $\begin{array}{l}\text { Shenzhen Second People's Hospital } \\
\text { Shenzhen, Guangdong, China }\end{array}$ & $\begin{array}{l}\text { Shenzhen Geno-Immune } \\
\text { Medical Institute }\end{array}$ \\
\hline BNT162a1 & Phase-3 & NCT04368728 & $\begin{array}{l}\text { NYU Langone Health New York, New } \\
\text { York, United States }\end{array}$ & Pfizer/Biotech SE \\
\hline $\begin{array}{l}\text { Recombinant novel } \\
\text { coronavirus vaccine }\end{array}$ & Phase-2 & NCT04341389 & $\begin{array}{l}\text { Hubei Provincial Center for Disease } \\
\text { Control and Prevention Wuhan, } \\
\text { Hubei, China }\end{array}$ & CanSino Biologics Inc. \\
\hline BCG & Phase-4 & NCT04369794 & $\begin{array}{l}\text { Hospital das Clínicas Unicamp } \\
\text { Campinas, }\end{array}$ & University of Campinas, Brazil \\
\hline SCB-2019 & Phase-1 & NCT04405908 & $\begin{array}{l}\text { Linear Clinical Research Ltd } \\
\text { Nedlands, Western Australia, } \\
\text { Australia }\end{array}$ & $\begin{array}{l}\text { Clover Biopharmaceuticals, } \\
\text { AUS Pty Ltd. }\end{array}$ \\
\hline bac-TRL-Spike & Phase-1 & NCT04334980 & $\begin{array}{l}\text { Canadian center for Vaccinology } \\
\text { Dalhousie University, IWK Health } \\
\text { Centre Halifax, Nova Scotia, Canada }\end{array}$ & Symvivo Corporation \\
\hline $\begin{array}{l}\text { Inactivated SARS- } \\
\text { CoV-2 vaccine }\end{array}$ & $\begin{array}{l}\text { Phase- } \\
1 / 2\end{array}$ & NCT04412538 & $\begin{array}{l}\text { West China Second University } \\
\text { Hospital, Sichuan University, China }\end{array}$ & $\begin{array}{l}\text { Chines Academy of Medical } \\
\text { Sciences }\end{array}$ \\
\hline ChAdOx1 nCoV-19 & Phase-3 & NCT04324606 & $\begin{array}{l}\text { University Hospital Southampton NHS } \\
\text { Foundation Trust Southampton, } \\
\text { Hampshire, United Kingdom }\end{array}$ & University of Oxford \\
\hline IMM-101 & Phase-3 & NCT04442048 & Canadian Cancer Trials Group & $\begin{array}{l}\text { Canadian Cancer Trials Group, } \\
\text { BioCan Rx }\end{array}$ \\
\hline INO-4800 & Phase-1 & NCT04336410 & $\begin{array}{l}\text { University of Pennsylvania } \\
\text { Philadelphia, Pennsylvania, United } \\
\text { States }\end{array}$ & Inovio Pharmaceuticals \\
\hline $\begin{array}{l}\text { Alum-adjuvanted, } \\
\text { formalin-inactivated } \\
\text { vaccine }\end{array}$ & $\begin{array}{l}\text { Phase } \\
1 / 2\end{array}$ & NCT04282574 & $\begin{array}{l}\text { Renqiu City Center for Disease } \\
\text { Control and Prevention, Renqiu, } \\
\text { Hebei, China }\end{array}$ & $\begin{array}{l}\text { Sinovac Research and } \\
\text { Development Co., Ltd. }\end{array}$ \\
\hline $\begin{array}{l}\text { Alum-adjuvanted, } \\
\text { formalin-inactivated } \\
\text { vaccine }\end{array}$ & $\begin{array}{l}\text { Phase } \\
1 / 2\end{array}$ & NCT04352608 & $\begin{array}{l}\text { Suining County Center for Disease } \\
\text { Control and Prevention Xuzhou, } \\
\text { Jiangsu, China }\end{array}$ & $\begin{array}{l}\text { Sinovac Research and } \\
\text { Development Co., Ltd. }\end{array}$ \\
\hline $\begin{array}{l}\text { Vectored vaccine: } \\
\text { Adenovirus Type } 5 \\
\text { Vector }\end{array}$ & Phase 2 & NCT04313127 & $\begin{array}{l}\text { Institute of Biotechnology, Academy } \\
\text { of Military Medical Sciences. PLA of } \\
\text { China, Jiangsu Province Centers for } \\
\text { Disease Control and Prevention, }\end{array}$ & CanSino Biologics Inc., \\
\hline
\end{tabular}




\begin{tabular}{|l|l|l|l|l|}
\hline & & & $\begin{array}{l}\text { Hubei Provincial Center for Disease } \\
\text { Control and Prevention, Tongji } \\
\text { Hospital }\end{array}$ & \\
\hline $\begin{array}{l}\text { Vectored vaccine: } \\
\text { with spike protein }\end{array}$ & $\begin{array}{l}\text { Phase } \\
\text { wirus Type }\end{array}$ & NCT04437875 & $\begin{array}{l}\text { Sechenov First Moscow State Medical } \\
\text { University, Moscow, Russian } \\
\text { Federation, }\end{array}$ & $\begin{array}{l}\text { Gamaleya Research Institute } \\
\text { of Epidemiology and } \\
\text { Microbiology, Health Ministry } \\
\text { of the Russian Federation, } \\
\text { Acellena Contract Drug } \\
\text { Research and Development }\end{array}$ \\
\hline $\begin{array}{l}\text { Artificial APCs } \\
\text { expressing SARS- } \\
\text { CoV-2 proteins }\end{array}$ & $1 / 2$ & NCT04386252 & $\begin{array}{l}\text { Hoag Memorial Hospital Presbyterian, } \\
\text { Newport Beach, California, United } \\
\text { States }\end{array}$ & Aivita Biomedical, Inc. \\
\hline $\begin{array}{l}\text { Nanoparticle vaccine } \\
\text { with Matrix-M } \\
\text { adjuvant }\end{array}$ & Phase 1 & NCT04368988 & $\begin{array}{l}\text { Advanced Clinical Research, Meridian, } \\
\text { Idaho, United States }\end{array}$ & Novavax \\
\hline
\end{tabular}

\section{Conclusion}

Despite the serious study of SARS-COV2, more pieces of information are required to be revealed about the pathology of the virus. Many research-related quarries remain to be answered and effective drug or/and safe vaccines against SARS-COV2 infection, which is the need the hours remaining to be recognized. With a sensible plan of clinical openings, significant and logical research is essential to determine the effectiveness of the applied medications. We have tried to summarize some of the SAR-nCoV2 treatments that essentially focus on the potential drugs. Also, we need to know the components of viral virality and use this information to carefully develop the vaccines. To comprehend viral pathogenesis, one must realize how the immune system intervenes with the virus. It is also justified to seek the production of several vaccine varieties, including those against other target antigens, to increase the chances of efficacy. The best choice for increasing the percentage of the population immune to SARS-CoV2 is to use vaccines that induce neutralizing antibodies on a wide scale. Herd immunity may be achieved by vaccination, while widespread natural infection tends to be too dangerous for humans and the economy, unless viral transmission induces immunity in far greater fractions of the world's population than currently understood and anticipated, probably in countries with laxer anti-viral steps. COVID-19 vaccination is given top priority due to the urgency.

\section{References}

1. Taylor DR. Obstacles and advances in SARS vaccine development. Vaccine 2006; 24(7):863-71.

https://doi.org/10.1016/j.vaccine.2005.08.102

2. Liu C, Zhou Q, Li Y, Garner L V, Watkins SP, Carter LJ, et al. Research and Development on Therapeutic Agents and Vaccines for COVID-19 and Related Human Coronavirus Diseases. ACS Cent Sci 2020; 6:315-31. https://doi.org/10.1021/acscentsci.0c00272

3. Rickie DO. The Lancet Medical Countermeasures Analysis of 2019-nCoV and Vaccine Risks for Antibody. Lancet (London, England) 2020. https://doi.org/10.2139/ssrn.3546070

4. Tu YF, Chien CS, Yarmishyn AA, Lin YY, Luo YH, Lin YT, et al. A review of sars-cov- 2 and the ongoing clinical trials. Int J Mol Sci 2020; 21. https://doi.org/10.3390/ijms21072657

5. Who.int. 2021. COVID-19 Situation Reports. [online] Available at https://www.who.int/emergencies/diseases/novelcoronavirus-2019/situation-reports, Cited 12 April 2021.

6. Zhu N, Zhang D, Wang W, Li X, Yang B, Song J, et al. A novel coronavirus from patients with pneumonia in China, 2019. N. Engl J Med 2020; 382:727-33. https://doi.org/10.1056/NEJMoa2001017

7. Lu R, Zhao X, Li J, Niu P, Yang B, Wu H, et al. Genomic characterization, and epidemiology of 2019 novel coronavirus: implications for virus origins and receptor binding. Lancet 2020; 395:565-74.

https://doi.org/10.1016/S0140-6736(20)30251-8

8. Wu Z, Yang L, Ren X, Zhang J, Yang F, Zhang S, et al. ORF8-related genetic evidence for Chinese horseshoe bats as the source of

human severe acute respiratory syndrome coronavirus. J Infect Dis 2016; 213:579-83. https://doi.org/10.1093/infdis/jiv476

9. Ren LL, Wang YM, Wu ZQ, Xiang ZC, Guo L, Xu T, et al. Identification of a novel coronavirus causing severe pneumonia in humans: a descriptive study. Chin Med J (Engl) 2020; 133: 1015-24. https://doi.org/10.1097/CM9.0000000000000722

10. Wan Y, Shang J, Graham R, Baric RS, Li F. Receptor Recognition by the Novel Coronavirus from Wuhan: An Analysis Based on Decade-Long Structural Studies of SARS Coronavirus. J Virol 2020; 94(7):1-9. https://doi.org/10.1128/JVI.00127-20

11. Rothan HA, Byrareddy SN. The epidemiology and pathogenesis of coronavirus disease (COVID-19) outbreak. J. Autoimmun 2020; 109:102433.

https://doi.org/10.1016/j.jaut.2020.102433

12. Nyayanit DA, Sarkale P, Baradkar S, Patil S, Yadav PD, Shete-Aich A, et al. Transcriptome \& viral growth analysis of SARS-CoV-2infected Vero CCL-81 cells. Indian J Med Res 2020; 152:70-6. https://doi.org/10.4103/ijmr.IJMR_2257_20

13. Hoffmann M, Kleine-Weber H, Schroeder S, Krüger N, Herrler T, Erichsen S, et al. SARS-CoV-2 Cell Entry Depends on ACE2 and TMPRSS2 and Is Blocked by a Clinically Proven Protease Inhibitor. Cell 2020; 181:271-280.e8.

https://doi.org/10.1016/j.cell.2020.02.052

14. Prompetchara E, Ketloy C, Palaga T. Immune responses in COVID-19 and potential vaccines: Lessons learned from SARS and MERS epidemic. Asian Pacific J Allergy Immunol 2020; $38: 1-9$.

15. Chatterjee P, Nagi N, Agarwal A, Das B, Banerjee S, Sarkar S, et al. 
The 2019 novel coronavirus disease (COVID-19) pandemic: A review of the current evidence. Indian J Med Res 2020; 151:147-59. https://doi.org/10.4103/ijmr.IJMR_519_20

16. Phan LT, Nguyen TV, Luong QC, Nguyen HT, Le HQ, Nguyen TT, et al. Importation and human-to-human transmission of a novel coronavirus in Vietnam. N Engl J Med 2020; 382:872-4. https://doi.org/10.1056/NEJMc2001272

17. Go YY, Kim Y, Cheon S, Nam S, Ku B, Kim M, et al. Clinical features of patients infected with 2019 novel coronavirus in Wuhan, China. Lancet 2020; 395:497-506 https://doi.org/10.1016/S0140-6736(20)30183-5

18. Li Z, Wu M, Yao J, Guo J, Liao X, Song S, et al. Caution on Kidney Dysfunctions of COVID-19 Patients. SSRN Electron J 2020; 1-25. https://doi.org/10.2139/ssrn.3559601

19. Moujaess E, Kourie H, Ghosn M. Cancer patients and research during COVID-19 pandemic: A systematic review of current evidence. Critical Rev Oncology/Hematology 2020; 150(10):2932.

https://doi.org/10.1016/j.critrevonc.2020.102972

20. Abd El-Aziz T, Stockand J. Recent progress and challenges in drug development against COVID-19 coronavirus (SARS-CoV-2) an update on the status. Infection, Genetics, and Evolution 2020; 83:104327.

https://doi.org/10.1016/j.meegid.2020.104327

21. Martina BEE, Haagmans BL, Kuiken T, Fouchier RAM, Rimmelzwaan GF, Van Amerongen G, et al. SARS virus infection of cats and ferrets. Nature 2003; 425:915. https://doi.org/10.1038/425915a

22. Zheng L, Zhang L, Huang J, Nandakumar KS, Liu S, Cheng K. Potential treatment methods targeting 2019-nCoV infection. Eur J Med Chem 2020; 205:112687.

https://doi.org/10.1016/j.ejmech.2020.112687

23. Marian AJ. Current State of Vaccine Development and Targeted Therapies for COVID-19: Impact of Basic Science Discoveries. Cardiovasc Pathol 2020; 50:107278.

https://doi.org/10.1016/j.carpath.2020.107278

24. Xie M, Chen Q. Insight into 2019 novel coronavirus - An updated interim review and lessons from SARS-CoV and MERS-CoV. Int J Infect Dis 2020; 94:119-24.

https://doi.org/10.1016/j.ijid.2020.03.071

25. Noorimotlagh Z, Karami C, Mirzaee SA, Kaffashian M, Mami S, Azizi M. Immune and bioinformatics identification of T cell and $\mathrm{B}$ cell epitopes in the protein structure of SARS-CoV-2: A systematic review. Int Immunopharmacol 2020; 86. https://doi.org/10.1016/j.intimp.2020.106738

26. Kim E, Erdos G, Huang S, Kenniston TW, Balmert SC, Carey CD, et al. Microneedle array delivered recombinant coronavirus vaccines: Immunogenicity and rapid translational development. E Bio Medicine 2020; 55:1-12.

https://doi.org/10.1016/j.ebiom.2020.102743

27. Li X, Geng M, Peng Y, Meng L, Lu S. Molecular immune pathogenesis, and diagnosis of COVID-19. J Pharm Anal 2020. 10(2):102-8. https://doi.org/10.1016/j.jpha.2020.03.001

28. Dawood AA. Mutated COVID-19 may foretell a great risk for mankind in the future. New Microbes New Infect 2020 35:100673. https://doi.org/10.1016/j.nmni.2020.100673

29. Kuttiatt VS, Abraham PR, Menon RP, Vaidya PC, Rahi M. Coronavirus disease 2019 in children: clinical \& epidemiological implications. Indian J Med Res 2020; 152:2140. https://doi.org/10.4103/ijmr.IJMR_977_20
30. Hamid S, Mir MY, Rohela GK. Novel coronavirus disease (COVID19): A pandemic (epidemiology, pathogenesis, and potential therapeutics). New Microbes New Infect 2020; 35:100679. https://doi.org/10.1016/j.nmni.2020.100679

31. Feld JJ, Jacobson IM, Sulkowski MS, Poordad F, Tatsch F, Pawlotsky JM. Ribavirin revisited in the era of direct-acting antiviral therapy for hepatitis C virus infection. Liver Int 2017; 37: 5-18. https://doi.org/10.1111/liv.13212

32. Richardson P, Griffin I, Tucker C, Smith D, Oechsle O, Phelan A, et al. Baricitinib as a potential treatment for $2019-\mathrm{nCoV}$ acute respiratory disease. Lancet 2020; 395:e30-1. https://doi.org/10.1016/S0140-6736(20)30304-4

33. Spagnuolo V, Castagna A, Lazzarin A. Darunavir for the treatment of HIV infection. Expet Opin Pharmacother 2018; 19(10):1149-63.

https://doi.org/10.1080/14656566.2018.1484901

34. Ding Q, Lu P, Fan Y, Xia Y, Liu M. The clinical characteristics of pneumonia patients coinfected with 2019 novel coronavirus and influenza virus in Wuhan, China. J. Med. Virol 2020; 92:1549- 55. https://doi.org/10.1002/jmv.25781

35. Decaro N, Lorusso A. Novel human coronavirus (SARS-CoV-2): A lesson from animal coronaviruses. Vet Microbiol 2020; 244:108693. https://doi.org/10.1016/j.vetmic.2020.108693

36. Le TT, Andreadakis Z, Kumar A, Román RG, Tollefsen S, Saville $M$, et al. The COVID-19 vaccine development landscape. Nat Rev Drug Discov 2020; 19:305-6. https://doi.org/10.1038/d41573-020-00073-5

37. Speiser DE, Bachmann MF. Covid-19: Mechanisms of vaccination and immunity. Vaccines 2020; 8(3):1-22. https://doi.org/10.3390/vaccines8030404

38. Algaissi AA, Alharbi NK, Hassanain M, Hashem AM Preparedness, and response to COVID-19 in Saudi Arabia: Building on MERS experience. J Infect Public Health 2020 13(6):834-8. https://doi.org/10.1016/j.jiph.2020.04.016

39. Vennema H, de Groot RJ, Harbour DA, Dalderup M, GruffyddJones T, Horzinek MC, et al. Early death after feline infectious peritonitis virus challenges due to recombinant vaccinia virus immunization. J Virol 1990; 64:1407-9. https://doi.org/10.1128/JVI.64.3.1407-1409.1990

40. Samrat SK, Tharappel AM, Li Z, Li H. Prospect of SARS-CoV-2 spike protein: Potential role in vaccine and therapeutic development. Virus Res 2020; 288:198141. https://doi.org/10.1016/j.virusres.2020.198141

41. Sheng WH, Ko WC, Huang YC, Hsueh PR. SARS-CoV-2 and COVID-19. J Microbiol Immunol Infect 2020; 53(3): 363-4 https://doi.org/10.1016/j.jmii.2020.03.033

42. Shi J, Wen Z, Zhong G, Yang H, Wang C, Huang B, et al. Susceptibility of ferrets, cats, dogs, and other domesticated animals to SARS-coronavirus 2. Science 2020; 368:1016-20 https://doi.org/10.1126/science.abb7015

43. Bao L, Deng W, Huang B, Gao H, Liu J, Ren L, et al. The pathogenicity of SARS-CoV-2 in hACE2 transgenic mice. Nature 2020; 583:830-3. https://doi.org/10.1038/s41586-020-2312-y

44. Rockx B, Kuiken T, Herfst S, Bestebroer T, Lamers MM, Munnink BBO, et al. Comparative pathogenesis of COVID-19, MERS, and SARS in a nonhuman primate model. Science 2020; 368:1012-5. https://doi.org/10.1126/science.abb7314

45. Liu C, Zhou Q, Li Y, Garner LV, Watkins SP, Carter LJ, et al. 
Research and development on therapeutic agents and vaccines for COVID-19 and related human coronavirus diseases. ACS Cent Sci 2020; 6:315-31.

https://doi.org/10.1021/acscentsci.0c00272

46. Al-Qahtani AA. Severe Acute Respiratory Syndrome Coronavirus 2 (SARS-CoV-2): Emergence, history, basic and clinical aspects. Saudi J Biol Sci 2020; 27(10):2531-8.

https://doi.org/10.1016/j.sjbs.2020.04.033

47. Tirado S, Yoon K. Antibody-Dependent Enhancement of Virus Infection and Disease. Viral Immunology 2003; 16(1):69-86. https://doi.org/10.1089/088282403763635465

48. Acosta PL, Caballero MT, Polack FP. Brief History and Characterization of Enhanced Respiratory Syncytial Virus Disease. Clin Vaccine Immunol 2016; 23(3):189-95. https://doi.org/10.1128/CVI.00609-15

49. Lan L, Xu D, Ye G, Xia C, Wang S, Li Y, et al. Positive RT-PCR Test Results in Patients Recovered from COVID-19. J Am Med Assoc 2020; 323:1502-3. https://doi.org/10.1001/jama.2020.2783

50. Wu A, Peng Y, Huang B, Ding X, Wang X, Niu P, et al. Genome Composition and Divergence of the Novel Coronavirus (2019nCoV) Originating in China. Cell Host Microbe 2020; 27:325-8. https://doi.org/10.1016/j.chom.2020.02.001
51. Pachetti M, Marini B, Benedetti F, Giudici F, Mauro E, Storici P, et al. Emerging SARS-CoV-2 mutation hot spots include a novel RNA-dependent-RNA polymerase variant. J Transl Med 2020; 18:1-9. https://doi.org/10.1186/s12967-020-02344-6

52. Peeples L. Avoiding pitfalls in the pursuit of a COVID-19 vaccine. Proc Natl Acad Sci 2020; 117:8218-21. https://doi.org/10.1073/pnas.2005456117

53. Belete TM. A review of promising vaccine development progress for COVID-19 disease. Vacunas, 2020. https://doi.org/10.1016/j.vacune.2020.10.009

54. Texas A\&M University. BCG vaccine for health care workers as a defence against COVID-19 (BADAS). 2021 Available from https://clinicaltrials.gov/ct2/show/NCT04348370, Cited 12 April 2021.

55. NIH, U.S National Library of Medicine. Clinical Trials.gov. 2021 Available at https://clinicaltrials.gov/ct2/results?cond=Covid+vaccine, Cited 12 April 2021. 